\title{
Role of Journalist during the European Election Campaign 2014 in Poland: Guide or Entertainer?
}

\section{Karolina Brylska, University of Warsaw, Poland}

\begin{abstract}
The article presents the results of a study of the behaviours of journalists as hosts of current affairs programs during election campaign. The goal of the study was to determine whether the discourse created by journalists is informative and explicative, i.e. to what degree does it attempt to explain to viewers the importance of the European Parliament elections and the operation of EU institutions, present candidate positions, their competencies and proposals, and interpret important political and social phenomena that accompany elections. The study was conducted as a quantitative and qualitative analysis of the content and discourse of current affairs programs broadcast by nationwide television stations in Poland two weeks prior to the European Parliament elections in May 2014. The study determined that journalists who hosted the broadcasts under review failed in their role as guides to the complicated political realities of the Euro elections campaign. Journalistic practices described in the article push political discourse towards theatricality and carnival-like qualities, but fail to improve the voters' level of knowledge of political processes and hence fail to engage them into shaping these processes.
\end{abstract}




\section{Introduction}

It has been long known that mass media are a very important source of information about the world around us - in its social, political, economical and cultural aspects (Luhmann, 2000, Castells, 2009). Mediatisation is indeed treated as a process of social change (Schulz, 2004, Hjavard, 2008, Livingstone, 2009). whereas the mediatisation of politics as one of the most important determinants of contemporary social practice appears to be an important challenge to democracy (Mazzoleni \& Schulz, 1999). In this context, the role of television seems to be crucial (Bourdieu, 1996). as it not only impacts our understanding and interpretation of the world (Luhmann, 2000). but also our political choices (McQuail, 2010: 503-536). Some even argue that television become more autonomous as a subfield of cultural production (Bolin, 2014).

Television gains special importance during election campaigns, when citizens pay more attention to political content in the medium. On one hand, they seek information about candidates and parties, and on the other, they are more frequently and clearly exposed to issues relating to the election. Two natural areas of presentation of political content, particularly during election campaign are news broadcasts and current affairs programs. And whereas the former type of broadcast is a relatively popular object of content analysis among media researchers, the latter is less often subject to comprehensive, in-depth description of content and actors (despite the fact that important political interviews during election campaign contribute significantly to the agenda-setting function, see McNair, 1995, Scammell \& Smetko, 2008).

Articles published about current affairs programs, and particularly about the role of journalists in these broadcasts usually concern themselves with the journalists' skills and tools, i.e. their strategies in asking questions and presenting arguments (Fetzer, 2007, HessLüttich, 2007, Lauerbach, 2007, Emmertsen, 2007, Komlósi \& Tarrósy, 2010). media-frame interactions in interviews (Fetzer, 2006, de Smedt, 2012). but also phenomena from the perspective of linguistic pragmatism, such as toughness (Gnisci et al., 2013) or irony (Hirsch \& Blum-Kulka, 2014) in journalistic speech.

One important conclusion from analyses carried out over recent years concerns the shifting model of conducting political interviews (Patrona, 2011, Tolson, 2012). The template model, practiced in American and many European (particularly British) television stations was the object of multiple studies (Clayman, 1992; Greatbatch, 1998; Clayman \& Heritage, 2002a). In this model, journalists asked questions from the position of a person representing "the viewers' interest" - in this sense they could naturally place themselves in opposition to the interviewee, but they were also obliged to maintain some level of neutrality or impartiality. The current model is described as "hybrid", i.e one where journalistic questions are asked alongside with open conflict with the interviewee (Hutchby, $2011 \mathrm{a}, \mathrm{b}$ ). This hybrid quality results from the combining of different categories of television interview, resulting on one hand in a confrontational and emotional quality, and on the other hand in the personalization of issues (Lauerbach, 2004, Ekstrom, 2011). The practice of interviewing in an antagonizing, hostile manner is even defined as „confrontainment” (Lorenzo-Dus, 2009). This is of course the consequence of changes in the media system as a whole. Phenomena such as tabloidization, the primacy of entertainment over information, increasing the dynamics of communication while trivializing the content contribute to the evolution of the journalists' skills and tools, as well as of their role in television programming. 
In connection with this evolution, the contemporary definition of a political interview, based on an observation of journalistic practices is as follows: „,[political interviews] are conducted in the form of dispute; their agendas are in part institutionally predetermined; they foreground public figures; unfold dialogically but also target overhearing audiences; have a high level of tolerance for equivocal talk; and allocate different interactional rights and obligations to interviewers and interviewees" (Kampf \& Daskal, 2011: 178-179). Key elements of this definition, also in context of the study presented in this article, include conflict as the basic form of communicative interaction, high exposure of ambivalent, evasive speech, as well as clash of (frequently conflicting) interests of the interlocutors.

Meanwhile, the journalist is a very important influencer. After Bourdieu: „Journalists - we should really say the journalistic field - owe their importance in society to their de facto monopoly on the large-scale informational instruments of production and diffusion of information. Through these, they control the access of ordinary citizens but also of other cultural producers such as scholars, artists, and writers, to what is sometimes called "public space," that is, the space of mass circulation" (1996: 46). The researcher also points to the crucial role of the moderator in political conversation (illustrated with the example of a debate): „First, there's the moderator. Viewers are always stuck by just how interventionist the moderator is. He determines the subject and decides the question up for debate (which often, as in Durand's debate over "should elites be burned?", turns out to be so absurd that the responses, whatever they are, are absurd as well). He keeps debaters in line with the rules of the game, even and especially because these rules can be so variable. (...) The moderator decides who speaks, and he hands out little tokens of prestige" (1996: 31). It can be concluded that such an important role gives certain advantages, but it should also be associated with certain responsibilities.

Given this determinant, and referring to the normative approach to the role of the journalist in a democratic society, the author postulates that during election campaign, journalists should act as guides to political reality for viewers. It appears they possess both the tools and the legitimization to do so. Naturally, this task requires neutrality and objectivity, as well as - or perhaps in the first place - the skill to conduct interviews with guests (politicians or experts) in such a way as to enable the viewer to understand the relevant political process, the content propounded by the candidate (e.g. credibility and consequences of political proposals). as well as the importance of the elections themselves. This challenge seems particularly important in context of the European Parliament elections, which least engage citizens and concern issues least known and most abstract to voters in nation states. Naturally, this model of political journalism should be practiced first of all in public media, which are obligated to realize their public mission (based on the Broadcasting Act in Poland, adopted in 1992 and amended many times). However, it can be assumed that for commercial stations this model could serve as a template - a type of best practice guideline - which at least the prestigious current affairs programs could aspire to.

\section{Methodology}

The results of the study presented in this article constitute part of a broad research project carried out by the research team of the Laboratory of Media Studies at University of Warsaw (under the guidance of the author and Tomasz Gackowski $\mathrm{PhD}$ ) in cooperation with the National Broadcasting Council in Poland. The purpose of the study was to reconstruct the Polish media discourse (more precisely: television discourse) during the European Parliament election campaign. The researchers sought to assess to what extent the discourse is 
informative and explicative, i.e. to what extent it attempts to explain to viewers the importance of EP elections and the functioning of EU institutions, familiarize them with candidate positions, their competencies and campaign proposals, as well as interpret important political and social phenomena accompanying elections (in case of the campaign under review, this included e.g. the increase in popularity of Euro-sceptic parties).

The study was conducted as a quantitative and qualitative analysis of the content and discourse analysis. The material was analyzed broadly and in-depth via a code key consisting of several dozen categories plus a special qualitative analysis card with in-depth descriptive categories (filled in for each programme). The analysis also utilized full transcripts of journalist speech. The study included following areas of research (in brief): thematization of the discourse (topics discussed and self-reference of the media system). guests (types of guests, their time of exposure, their rhetoric and argumentation strategies). structure of the programmes, anchors-journalists (their communication styles, questioning strategies, interactions withs guests and self-presentation). but also missionary values of television (according to Polish law: pluralism, impartiality, balance, integrity, quality) and, last but not least, role and image of women presented on air. To achieve the goals of the study, the researcher adopted the following criteria of qualifying materials to the study sample:

- the program was broadcast in nationwide television and exhibited the qualities of a current affairs program (genre criterion);

- the program was broadcast between 10 May (beginning of monitoring and 23 May (last day prior to election silence) (time criterion);

- presence in the broadcast of a European Parliament candidate, or the topic of EP elections as the main topic of the discussion (representing at least $50 \%$ of the duration of the broadcast).

The programs under analysis were broadcast in six major TV stations in Poland in terms of viewership and impact factor: general TV stations, public stations (TVP1 and TVP2). public news program TVP Info, commercial news programs TVN24 and Polsat News and TV Trwam, a social and catholic station.

\section{Findings}

In total, the analysis covered nearly 55 hours of audiovisual material. The chart below summarizes the number of unique current affairs materials included in the sample

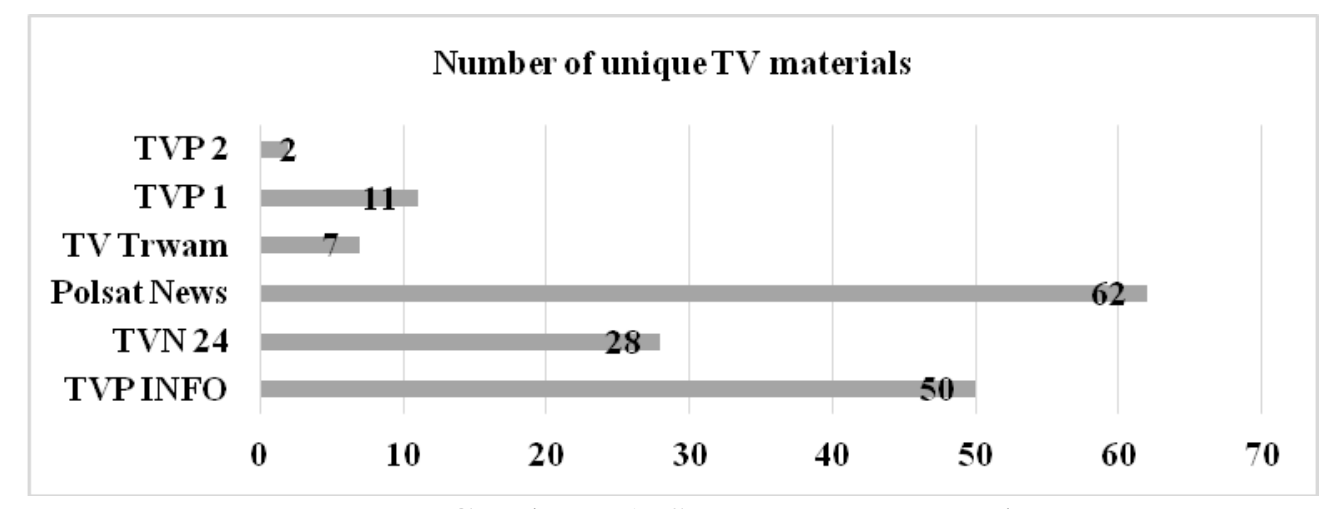

Graph no. 1. Source: own research

The large number of unique materials is due to the two main factors shaping the program line-up of these channels: 
- regular broadcasting of materials (daily, steady level of interest in the topic of elections)

- rich current affairs program line-up with strong saturation with election issues - in practice, only news channels discussed the issue of EP elections in more than one dedicated current affairs program daily.

Both these observations plus the quantitative tally list seem to legitimize the hypothesis that the main carrier of current affairs content in the European Parliament campaign were specialized news channels, followed by, to a lesser degree, general topic channels. In the course of the study, the researcher analyzed several key issues concerning the choice and behaviour of the hosts of the analyzed current affairs broadcasts. Under review were the verbal and non-verbal behaviours of journalists, the use of value judgment phrasing and gesticulation, the asking of questions of guests and the manner of argumentation (rhetoric and erothetics).

\section{Verbal Behaviours of Journalists}

In the quantitative analysis, the researcher applied the journalistic language load index, the purpose of which was to provide a cross cut view of the degree to which journalists in a given program use neutral language, without loaded phrasing (low index values) or the opposite language containing many evaluative and emotive phrases (high index values, even when not directed at guests of the program). The following operating definition of loaded language was adopted: "nouns containing strong positive or negative connotations (e.g. prostitute, bribe) of which non-loaded synonyms exist (e.g. woman of easy virtue, private financial gain); emotive language - nouns and adjectives illustrating the journalist's emotional state (resentment, appalled, concerned, touched). value judgment language - evaluative adjectives (good, terrifying, evil, horrible)."

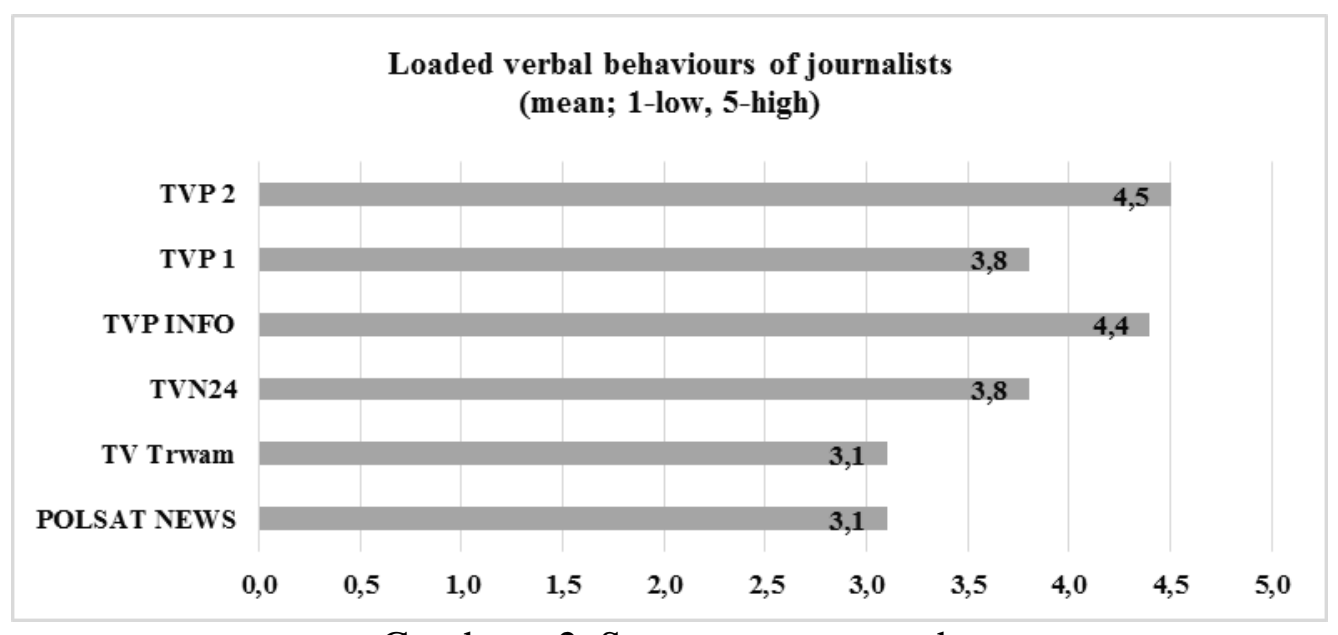

Graph no. 2. Source: own research

A comparison of the degree of use of loaded language by journalists showed that journalists from public television programs in general use loaded language more often. Good results (low index values) were achieved by Polsat News and TV Trwam.

As an accessory measure of text comprehensibility (aside from loading coded in a qualitative way) it is also possible to use the Gunning Fog index (Fog index, Gunning 1952). a measure developed by American Robert Gunning to assess the complexity of different kinds of texts 
(from press releases and marketing texts to journalistic and legal writing). All quotes from journalists hosting the programs were written down, and the finished transcripts were then analyzed according to a relevant algorithm. The index values based on transcripts of journalist quotes (illustrating the complexity of their language) for the analyzed sample are as follows:

\begin{tabular}{|l|l|}
\hline \multicolumn{2}{|c|}{ Index } \\
\hline Polsat News & 13,15 \\
\hline TV Trwam & 14,13 \\
\hline TVN 24 & 13,23 \\
\hline Mean for commercial TV: & $\underline{\mathbf{1 3 , 5 0}}$ \\
\hline TVP 1 & 12,61 \\
\hline TVP 2 & 11,68 \\
\hline TVP INFO & 13,40 \\
\hline Mean for public TV: & $\underline{\mathbf{1 2 , 5 6}}$ \\
\hline
\end{tabular}

Table no. 1. Source: own research

The values of the fog index can be approximately interpreted as the number of years of education required to understand the text in question. The boundary value is assumed to be 13 - this represents the threshold of comprehensibility for people without higher (tertiary) education. In the analyzed sample this value was achieved by TVP 1 and TVP 2, i.e. general programming channels, whereas all commercial news channels and TV Trwam (highest difficulty language in general, confirmed by observations made also with another indicators in the analysis) achieved a value of above 13 points. This result shows that the language of public debate during election campaign scored in the upper part of the difficulty scale of journalistic language - some broadcasts were likely to cause a degree of difficulty to viewers.

\section{Non-Verbal Behaviours of Journalists}

A factor that clearly differentiated individual broadcasts was the value of the total averaged index of non-verbal behaviours of journalists. The following operating definition of loaded non-verbal behaviours was adopted: grimaces of mimic muscles, eye movements suggesting an emotional attitude towards the topic of the conversation, gesticulation - gestures of hands, motions of the arms and head, shifts in the stance illustrating the journalist's positive or negative attitude to the interviewee, paraverbal aspects - raising one's voice, shouting, shifting tone or pitch to illustrate irony, aggression or clear approval for the interviewee. After Bourdieu, non-verbal communication and paralanguage are very important for understanding and establishing relations in communications: „There are so many registers of human expression, even on the level of the words alone-if you keep pronunciation under control, then it's grammar that goes down the tubes, and so on - that no one, not even the most self-controlled individual, can master everything, unless obviously playing a role or using terribly stilted language. The moderator intervenes with another language, one that he's not even aware of, which can be perceived by listening to how the questions are posed, and their tone" (1996: 31-32). 


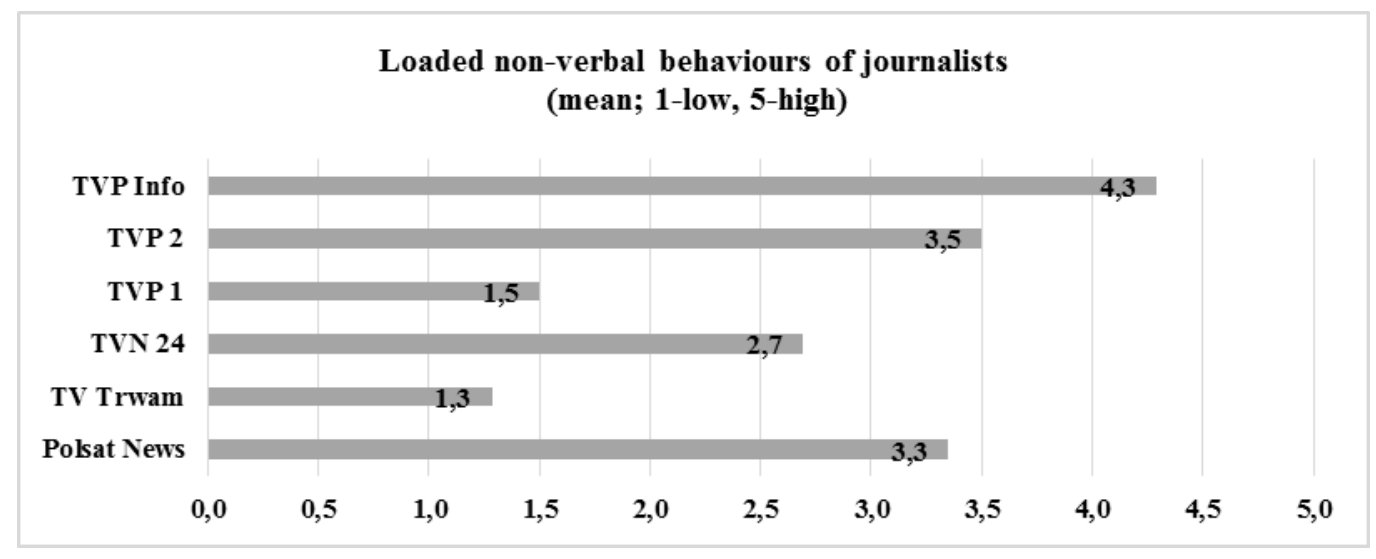

Graph no. 3. Source: own research

High values on this scale (i.e. broadcasts which featured strongly loaded non-verbal behaviours of program hosts such as smiling, explicit gesticulation, meaningful head and eye motions) were scored particularly by public television channels - TVP INFO and TVP $2-$ followed by Polsat News and TVN 24.

\section{Questioning Strategies of Journalists}

The next aspect under review was the questioning strategies applied by journalists. Two types of questions were defined: questions about information and about opinion. As questions about information, the researcher qualified questions the response to which could be ascribed the truth/false differentiation; i.e. questions about specific facts, data, events, persons. As questions about opinion, the researcher qualified those that included requests for the evaluation of specific facts, events, situations, persons, made along the line of good-bad; i.e. these were mostly open questions which encourage loaded, evaluative answers.

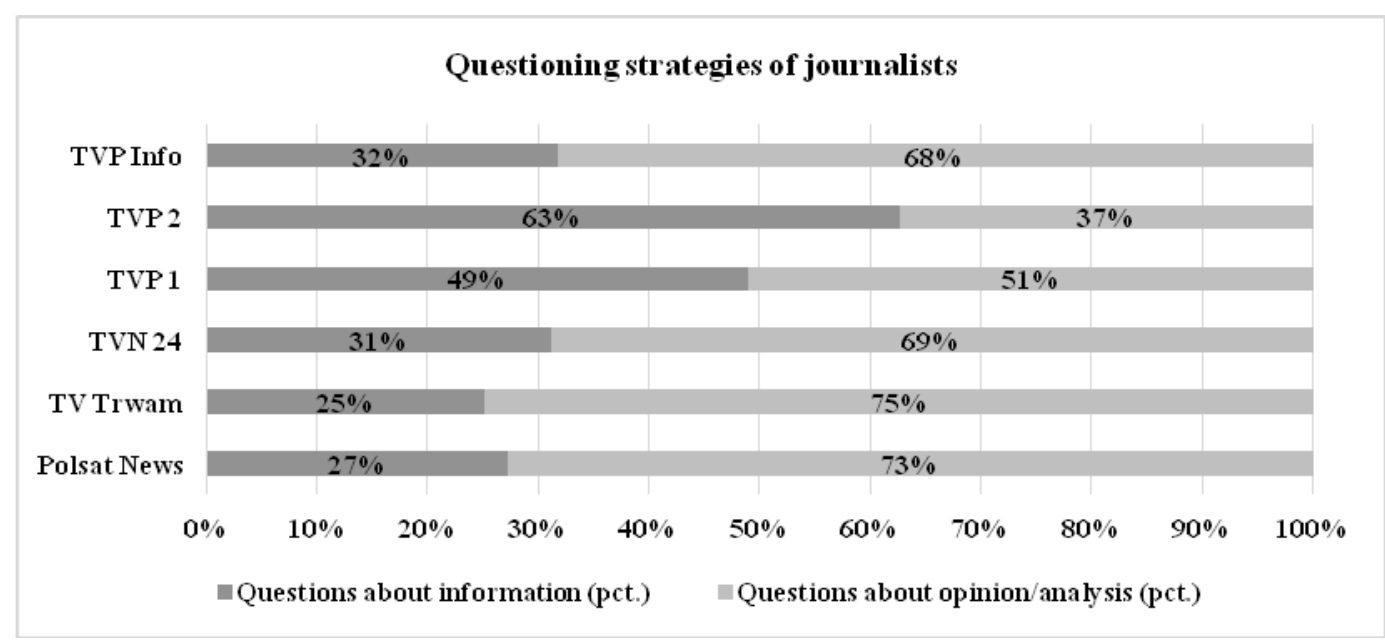

Graph no. 4. Source: own research

In case of all television channels - with the exception of TVP 2, from which only one program made it into the sample - there was a clear dominance of questions about opinions, which start the main part of the journalistic discussions in the broadcasts under review. It is clear that in the analyzed materials, journalism is tantamount to discussions of the opinions of the guests or forecasts of the development of the situation, not facts or information concerning, e.g. the essence of the work of the European Parliament. The table below presents the question index, i.e. on average, how many questions about information, 
questions about opinion, and total number of questions was asked by journalists in public and non-public television per minute - number of questions per broadcast duration.

\begin{tabular}{|c|c|c|c|c|}
\hline & $\begin{array}{c}\text { Average } \\
\text { questions about } \\
\text { information } \\
\text { per minute } \\
\text { (information } \\
\text { questions index } \\
- \text { IQI) }\end{array}$ & $\begin{array}{c}\text { Average } \\
\text { questions } \\
\text { about opinion } \\
\text { per minute } \\
\text { (opinion } \\
\text { questions } \\
\text { index - OQI) }\end{array}$ & $\begin{array}{c}\text { Average total } \\
\text { questions per } \\
\text { minute } \\
\text { (question } \\
\text { index - QI) }\end{array}$ & $\begin{array}{c}\text { Number of } \\
\text { questions } \\
\text { in total }\end{array}$ \\
\hline $\begin{array}{c}\text { POLSAT } \\
\text { NEWS }\end{array}$ & 0.23 & 0.60 & 0.83 & 695 \\
\hline TV TRWAM & 0.18 & 0.49 & 0.68 & 103 \\
\hline TVN 24 & 0.37 & 0.62 & 0.99 & 600 \\
\hline TVP INFO & 0.22 & 0.44 & 0.67 & 637 \\
\hline TVP 1 & 0.52 & 0.42 & 0.94 & 225 \\
\hline TVP 2 & 0.48 & 0.27 & 0.74 & 64 \\
\hline $\begin{array}{c}\text { AVERAGE/TO } \\
\text { TAL }\end{array}$ & 0.33 & 0.47 & 0.81 & 2324 \\
\hline $\begin{array}{l}\text { AVERAGE/TO } \\
\text { TAL FOR } \\
\text { NON-PUBLIC } \\
\text { CHANNELS }\end{array}$ & 0.26 & 0.57 & 0.83 & 1398 \\
\hline $\begin{array}{c}\text { AVERAGE/TO } \\
\text { TAL FOR } \\
\text { PUBLIC } \\
\text { CHANNELS }\end{array}$ & 0.41 & 0.38 & 0.78 & 926 \\
\hline
\end{tabular}

Table no. 2. Source: own research

According to this tally list, on average, in the time under review, more questions about information per minute were asked by journalists in public media, with TVP1 ranking first. As far as questions about opinion are concerned - the opinion question index (henceforth: OQI) - significantly higher index values were achieved by non-public channels -0.57 , with public channels scoring just 0.38 . Referring to the previous chart, it is worth noting that the predominance of questions about opinion is enormous, which is why the values of individual broadcasts for the OQI index were much higher than those reported with the information question index (IQI). Programs broadcast in public television, covered by the monitoring, were characterized by a much higher average number of questions about information per minute of broadcast - IQI: 0.41. For non-public channels, this index scored just 0.26 . This is due to the fact that public television journalists much more frequently asked questions about information, i.e. facts, issues more concrete and more cognitively valuable than questions about opinion, which by definition are characterized by a certain looseness, strong subjectivism and in most cases relatively higher ease of response. In this context it could be assumed that the better program (on account of facts and the program's information value) would be the one where the journalist asks more information-related questions, especially with the European Parliament elections, which enjoy little popularity due to the fact that the level of knowledge about EU institutions (their function, importance and role) is relatively low among Poles. 
One may attempt to generalize that the division into questions about information and questions about opinion today constitutes a characteristic factor differentiating non-public from public channels on the panoramic level of results (for individual programs and their editions there may be significant variations depending on individual hosts and selection of guests). From the perspective of the viewer-voter, who primarily values information and knowledge about the European Union that can be obtained from watching current affairs programming on television, it is public television that would more likely be the better choice, however with all the reservations concerning drawing conclusions only on the level of synthetic, panoramic-level results for individual channels. As far as the average number of question in total asked per minute in the reviewed broadcasts, a higher result was reported for non-public channel programs -0.83 ; and a slightly lower result for public television -0.78 questions per minute of broadcast. In this tally, it is difficult to determine the more or less desirable number of questions that journalists should ask their guests, from the perspective of the viewer-voter. This is indeed a very relative issue which depends on many factors that were not included in this article due to volume constraints.

It is impossible clearly determine (on the synthetic, panoramic level) what it means that a given broadcast on a given channel included more or fewer questions per minute. Is it good that there were fewer questions? Is it bad that there were more? This, of course, depends on many factors. That is why it is worth to compare the results concerning questions asked by the journalist and addressed to his guests in the context of interventions - i.e. the number of interruptions by the journalist per minute of programming covered by monitoring.

\section{Journalists' Interventions}

The table below presents the results of the average intervention index (henceforth: II) for all channels covered by monitoring, based on eligible analyzed situations. Additionally, included is the total number of interventions identified and codified during the study in each broadcast covered by monitoring, constituting part of the current affairs program line-up of individual channels during the last two weeks of the EP election campaign. It is also worth noting, that interventions included all cases of interruption of the speaking guest by journalist, as well as attempts to interrupt (e.g. by raising the hand or monosyllabic attempts at interruption).

\begin{tabular}{|l|c|c|}
\hline & $\begin{array}{c}\text { Intervention index (II) } \\
\text { - the average number } \\
\text { of interruptions per } \\
\text { minute }\end{array}$ & $\begin{array}{c}\text { Number of } \\
\text { interruptions in } \\
\text { general }\end{array}$ \\
\hline POLSAT NEWS & $\mathbf{1 , 1 3}$ & $\mathbf{8 4 5}$ \\
\hline TV TRWAM & $\mathbf{0 , 6 8}$ & $\mathbf{1 0 4}$ \\
\hline TVN 24 & $\mathbf{1 , 7 7}$ & $\mathbf{8 6 7}$ \\
\hline TVP INFO & $\mathbf{1 , 2 4}$ & $\mathbf{1 2 0 9}$ \\
\hline TVP 1 & $\mathbf{1 , 8 2}$ & $\mathbf{4 2 1}$ \\
\hline TVP 2 & $\mathbf{1 , 6 8}$ & $\mathbf{1 4 5}$ \\
\hline AVERAGE/TOTAL & $\mathbf{1 , 3 9}$ & $\mathbf{3 5 9 1}$ \\
\hline $\begin{array}{l}\text { AVERAGE/TOTAL FOR PUBLIC } \\
\text { TV }\end{array}$ & $\mathbf{1 , 3 4}$ & $\mathbf{1 8 1 6}$ \\
\hline AVERAGE /TOTAL FOR & 1,58 & 1775 \\
\hline COMMERCIAL TV & & \\
\hline
\end{tabular}

Table no. 3. Source: own research 
According to the tally, the highest number of interventions was noted in TVP INFO - exactly 1209. Ranking second was the commercial channel TVN 24 with 867 and Polsat News with 845. If we look closer at the values of the intervention index (II) for individual programs, we will see that for every minute of broadcast, the most frequent interrupters were journalists of public television channels - TVP 1 (II: 1.82); followed by TVN 24 (II: 1.77) and TVP 2 with a relatively high result for only two one-hour broadcasts - II: 1.68. Polsat News achieved and average result of just 1.13 interventions per minute of broadcast. Compared to other channels - especially the commercial TVN 24 - this is a relatively low result. The only channel with a lower result was TV Trwam, which is clearly different from other broadcasts, e.g. in the onesidedness of guest selection - II: 0,68.

It would appear that interrupting guests very frequently cannot be considered a good journalistic practice. In one extreme example, there were 64 journalist interventions in a 12 minute and 19 second broadcast - the intervention index for this particular program was 5.19, i.e. more than five interventions per minute, which means the journalist had interrupted their guest almost ever 11.5 seconds on average. This kind of attitude certainly allows the hosting journalist to dominate over their guest. It is also likely to discompose the guest (as observed in some analyzed broadcasts). However, it is unlikely that the viewer will gain any insights from such a sliced up broadcast. The educational value of such a program is therefore close to none - such practices can attract attention, but only through the temperature of the confrontation and its form, not the content or essence.

The channel where journalists interrupted the least is undoubtedly Polsat News - also a commercial station, which is worth emphasizing, keeping in mind the results of TVN, which competes for the same viewer and follows the same business logic (telemetric). It is worth noting that Polsat News also broadcast programs where the hosts never interrupted their guests - the intervention index was exactly zero. It turns out that hosting a program on a commercial channel without interrupting the guest is possible.

It is worth remembering that on the general level - without accounting for divisions into e.g. guests and taking into consideration the time devoted to each guest - one cannot place a judgment value on the fact that there were e.g. more questions or more interventions per minute. These kinds of comparisons are of limited benefit without the qualitative analyses also conducted as part of this monitoring. This data should be read in a complementary fashion. It should be kept in mind that the manner in which questions are asked to a significant extent blends with the manner in which guests are interrupted, because often when journalists interrupt, it is to disagree with something, add something, or point out a flaw in the speaker's reasoning, but also often to ask the next question, which is why these two measures should be reviewed in complement, while naturally placing significant importance on the results of qualitative analyses dedicated to individual broadcasts, channels and individual journalists hosting the programs.

\section{Conclusions and Discussion}

Following these analyses, it is worth considering what the perfect current affairs program would look like. What should there be more of, and what is excessive? What proportions should there be between e.g. questions about opinions and questions about information? And finally: how many questions in all should there be during a specific running time, and how many journalist interventions should be expected in an interview with a politician? These are not easy questions, and the results presented below cannot provide clear answers. However, it 
can be assumed that the perfect current affairs program concerned with Euro elections on television would be one where the viewer-voter would learn as much as possible about the European Union to understand facts, events and circumstances, and the journalist would insist that their guest - the politician - answer questions straightforwardly, while allowing them to finish their sentences without constant interruptions. In this setting we would expect the majority of questions to be questions about information, with fewer questions about opinion. Hence all programs where these proportions are out of balance would not be considered taking these criteria into consideration - as close to the ideal. If this criterion were to be applied to the television broadcasts under review, then in the given research sample there would only be several such broadcasts. It should be emphasized once again that the evaluation of individual broadcasts, channels and journalists we cannot rely exclusively on the indicated indexes, calculated averages and aggregated quantitative data (we need to keep in mind the operational uncertainty posed by the questions themselves, wherein the journalist asks both about information and about opinion about the information). Equally important is the context, language and significance of individual question or intervention than just the fact of stating and counting the number of occurrences of the given behaviour.

In summary it should be stated that the current affairs programs under review are characteristic of political discourse in interviews in recent years, i.e.: presenting some discourse patterns (Fetzer, 2006; Lauerbach, 2006; Weizman, 2008) and shallow, partly irrelevant topics; with ongoing personalization (Thornborrow \& Montgomery, 2010); quite high degree of aggressiveness and argumentativeness as opposed to the traditionally conceived 'neutral' role of the broadcast news journalist (Eriksson, 2011, Hutchby, 2011a). The key research question would be to ask about the quality of the Polish political debate surrounding the European election. In other words, the authors of the study attempted to determine to what extent did current affairs programs under review succeed in explaining to the average viewer-voter the complexity of issues concerning the European Union and the essence of the functioning of the European Parliament? To what extent where they a helpful cognitive filter, providing a view on the key aspects, opportunities and risks involved in Poland's functioning within EU structures? As results of the study indicate, the answer to the question about the quality of the Euro elections debate in Poland is in the majority of cases negative. This means that most current affairs programs failed to explain the problems of contemporary Europe in a comprehensible and competent way. In most cases they failed to provide a diagnosis and summary of Poland's participation in EU structures, failed to explain the role and function of the European Parliament and other European agendas, such as the European Commission. They failed to enable the Polish viewer-voters to become familiar with the major accomplishments and failures of Polish members of the European Parliament. In most cases, they failed to define the major goals, challenges and opportunities facing Polish European Parliament members in the new term. It should be emphasized that other studies into the activity of Polish journalists in context of the election campaign to the national parliament showed similar behavior of journalists in conversations with politicians (Hordecki \& Piontek, 2014).

It is difficult to clearly define the reasons for such journalistic attitudes. If we were to assume that they not caused by time constraints, then the most probable reason for such journalistic inertia would be unpreparedness and ignorance. Were it otherwise, the knowledgeable journalist would certainly intervene by pointing to facts; take control over arguing politicians and coerce them into providing answers to concrete questions with answer that include numbers, percentages, tallies and various expert opinions. Journalists often ask about the 
politician's opinions and impressions simply because this requires less preparation. We can therefore once again concede to Pierre Bourdieu, who, writing about the so-called journalistic field, accused journalists of incompetence and unwillingness to learn, which they make up by being telegenic, politicking and biased.

The French philosopher observed that the journalistic field overpowers other fields through its media-based logic, to which increasing numbers of politicians, business people, experts and scientists succumb. Following Bourdieu, it is also worth noting that journalistic unpreparedness also results in unpreparedness on the part of the guest politicians. This creates an understanding of sorts, where both parties refrain from pointing out each other's incompetence. The journalist cannot accuse the politician of incompetence on the opinion level, because he or she would need to back it up with facts, numbers and data. This, however, would require much more involvement and time, which is plainly in short supply in contemporary media subjected to strong processes of tabloidization and commercialization.

This means that journalists who hosted the programs under review failed in their role as guides to the complicated political realities during the EP elections. The cardinal sins of the Polish journalists' skill- and toolset can be enumerated as follows:

- shallow disussions conducted (poor thematisation of the discourse).

- visible lack of wide knowledge on European Union, which causes inability to verify what politicians say and asking specialists the proper questions,

- questions about opinion dominate,

- frequent interventions (torn conversation).

- quite difficult language in some programmes (abstract terms, mental shortcuts).

- emotive language and meaningful non-verbal behavior,

- polarised guests' positions - because of the journalists confrontation between interviewees become normative part of the interaction.

These kinds of journalistic practices push political discourse towards theatricality and carnival-like qualities, but fail to improve the voters' level of knowledge of political processes, and hence fail to engage them into shaping these processes. We find ourselves in a society of the spectacle (Debord, 1967) and focus on behaviours based on consumption and entertainment

These observations match popular reflection of researchers about the evolution of the role of media in democracy, and the influence of media on democracy itself. Denton (2000) wrote that television has turned classic democracy into a political hybrid he named teledemocracy. Constructivists even claim that the media actually construct politics, and the proponents of the theory of colonization of political reality by the media believe that the media exert enormous pressure on politics and force political actors to accept media values (Street, 2005). The growing role of entertainment in television content (Postman, 1986) creates politainment or politicotainment (Meyer, 2002, Riegert, 2007). Naturally, the underlying causes of this state of affairs are economic: Barber (1995) writes that television is profit-driven, with all other values and goals subservient. This causes media institutions (including public media) to forego their concern for the public good.

These observations are just one step away from conceding to Dahlgren's (2001) opinion that politics are nothing but a media phenomenon and that politics do not exist outside of the media. And that would be a sad conclusion not just for media experts and political scientists, but first of all for the citizens. 


\section{References}

Barber, B. (1995). Jihad vs. McWorld: Terrorism's Challenge to Democracy. New York: Times Books.

Barnett, S. (2011). The Rise and Fall of Television Journalism : Just Wires and Lights in a Box?. London: Bloomsbury Pub. PLC.

Bennett, W. L., Entman, R. M. (2001). Mediated politics: communication in the future of democracy. Cambridge: Cambridge University Press.

Bolin, G. (2014). Television Journalism, Politics, and Entertainment: Power and Autonomy in the Field of Television Journalism. Television \& New Media, 15(4), 336-349.

Bolin, G., (2014). Television Journalism, Politics, and Entertainment: Power and Autonomy in the Field of Television Journalism, Television \& New Media, May, 15 (4), 336-349.

Bourdieu, (1996). On television, New York: The News Press.

Bull, , Meyer, K. (1988). Interruptions in political interviews: a study of Margaret Thatcher and Neil Kinnock. Journal of Language and Social Psychology, 7, 35-45.

Castells, M. (2009). Communication power, Oxford, New York: Oxford University Press

Clayman, S. (1992). Footing in the achievement of neutrality: the case of news interviews. In: Drew, P., Heritage, J. (Eds.). Talk at Work: Interaction in Institutional Settings, Cambridge: Cambridge University Press.

Clayman, S., Heritage, J. (2002a). The news interview: journalists and public figures on the air, Cambridge: Cambridge University Press.

Clayman, S., Heritage, J. (2002b). Questioning presidents: journalistic deference and adversarialness in the press conferences of US presidents Eisenhower and Reagan. Journal of Communication, 15, 749-775.

Dahlgren, (2001). The transformation of democracy? In: B. Axford, R. Huggins (eds.). New media and politics, London - Thousand-Oaks: Sage.

Day, R. (1989b). Interviewing politicians. In: I. Crewe, M. Harrop (Eds.). Political Communications: The General Election Campaign of 1987. Cambridge: CU.

De Smedt, E. (2012). Professionalism in political broadcast talk: The performance of a distancing journalistic self in formatted pre-election debates, Discourse, Context \& Media, 1, 114-122.

Debord, G. (1967). Society of the spectacle, Detroit: Black and Red.

Denton, R. (2000). Dangers of „teledemocracy”: How the medium of television undermines American democracy. In: R. Denton (eds.). Political communication ethics: An oxymoron? Westport: Praeger.

Ekstrom, M. (2011). Hybridity as a resourse and challenge in a talk show political interview. In: M. Ekstrom, M. Patrona (eds.). Talking Politics in Broadcast Media. Amsterdam: John Benjamins Publishing Co.

Emmertsen, S. (2007). Interviewers' challenging questions in British debate interviews, Journal of Pragmatics, 39, 570-591.

Eriksson, G., 2011. Adversarial moments: a study of short-form interviews in the news. Journalism 12, 51-69.

Fetzer, A. (2006). "Minister, we will see how the public judges you.' Media references in political interviews. Journal of Pragmatics, 38, 180-195.

Fetzer, A. (2007). Well if that had been true, that would have been perfectly reasonable. Appeals to reasonableness in political interviews. Journal of Pragmatics, 39, 13421359.

Gnisci, A., et al. (2013). A comparative study of toughness and neutrality in Italian and English political interviews. Journal of Pragmatics, 50, 152-167. 
Greatbatch, D. (1998). Conversation analysis: neutralism in British news interviews. In: A. Bell, Garrett (Eds.). Approaches to Media Discourse. Oxford: Blackwell.

Gunning, R. (1952). The Technique of Clear Writing. New York: McGraw-Hill.

Heritage, J., \& Greatbatch, D. (1992). On the institutional character of institutional talk: the case of news interviews. In: Boden, D., Zimmerman, D. (Eds.). Talk and Social Structure. Cambridge: Polity Press.

Hess-Lüttich, E. (2007). (Pseudo-)Argumentation in TV-debates. Journal of Pragmatics, 39, $1360-1370$.

Hirsch, G., Blum-Kulka, S. (2014). Identifying irony in news interviews. Journal of Pragmatics, 70, 31-51.

Hjarvard, S. (2008). The mediatization of society: A theory of the media as agents of social and cultural change. Nordicom Review, 29 (2), 105-134.

Hordecki, B., Piontek, D. (2014). Journalists and politicians in television interviews after elections: A redefinition of roles?. Central European Journal of Communication, 2 (2014), 209-224.

Hutchby, I. (2011a). Non-neutrality and argument in the hybrid political interview. Discourse Studies, 13 (3) 349-365.

Hutchby, I. (2011b). Doing non-neutral: belligerent interaction in the hybrid political interview. In: M. Ekstrom, M. Patrona (Eds.). Talking Politics in Broadcast Media: Cross Cultural Perspectives on Political Interviewing, Journalism and Accountability. Amsterdam: Benjamins.

J. Heritage (2002). The limits of questioning: negative interrogatives and hostile question content. Journal of Pragmatics, 34, 1427-1446.

Kampf, Z., Daskal, E. (2011). When the watchdog bites: insulting politicians on air. In: M. Ekstrom, M. Patrona, (Eds.). Talking Politics in Broadcast Media: Cross Cultural Perspectives on Political Interviewing, Journalism and Accountability. Amsterdam: Benjamins.

Komlósi, L., \& Tarrósy, I. (2010). Presumptive arguments turned into a fallacy of presumptuousness: Pre-election debates in a democracy of promises, Journal of Pragmatics, 42, 957-972.

Krippendorff, K. (1980). Content analysis. An introduction to its methodology, Beverly Hills: Sage.

Lauerbach, G. (2004). Political interviews as hybrid genre, Text - Interdisciplinary Journal for the Study of Discourse, 24(3), 353-397.

Lauerbach, G. (2007). Argumentation in political talk show interviews, Journal of Pragmatics, 39, 1388-1419.

Livingstone, S. (2009). On the mediation of everything: ICA presidential address 2008. Journal of Communication, 59 (1), 1-18.

Lorenzo-Dus, N. (2009). Television discourse: analysing language in the media. Basingstoke: Palgrave Macmillan.

Luhmann, N. (2000), The Reality of Mass Media, Stanford: Stanford University Press.

Mazzoleni, G., Schulz, W. (1999). "Mediatization" of Politics: A Challenge for Democracy?. Political Communication, 16(3), 247-261.

McCombs, M.E., \& D.L. Shaw. (1993). The Evolution of Agenda-Setting Research: TwentyFive Years in the Marketplace of Ideas. Journal of Communication, 43 (2), 58-67.

McNair, B. (1995). An introduction to political communication. London: Routledge.

McQuail's, D. (2010). McQuail's Mass Communication Theory, $6^{\text {th }}$ Edition, SAGE: Los Angeles. 
Meyer, T. (2002). Media democracy: How the media colonise politics, Cambridge: Polity Press.

Patrona, M. (2011). Neutralism revisited: when journalists set new rules in political news discourse. In: M. Ekstrom, M. Patrona (Eds.). Talking Politics in Broadcast Media: Cross Cultural Perspectives on Political Interviewing, Journalism and Accountability. Amsterdam: Benjamins.

Political Journalism in Transition. Western Europe in a comparative perspective (2013). R. Kuhn, R. K. Nielsen (eds.). London: I.B.Tauris.

Politicotainment. Popular culture and everyday life (2007). K. Riegert (eds). New York: Peter Lang Publishing.

Postman, N. (1986). Amusing Ourselves to Death. Public Discourse in the Age of Show Business, London: Heinemann.

Rendle-Short, J. (2007). Neutralism and adversarial challenges in the political news interview. Discourse and Communication, 1, 387-406.

Scammell, M., Smetko, H. (2008). Election news coverage in the UK. In: Stromback, J, Kaid, L. (Eds.). The Handbook of Election News Coverage Around the World. Routledge, New York.

Schulz, W. (2004). Reconstructing Mediatization as an Analytical Concept. European Journal of Communication, 19, 87-101.

Street, J. (2005). Politics lost, politics transformed, politics colonised? Theories of the impact of mass media. Political studies review, 3, 17-33.

Thornborrow, J., Montgomery, M. (eds) (2010). Personalisation in Broadcast News Interviews. Discourse and Communication, 4 (3).

Tolson, A. (2011). Political discourse in TV news: conversational presentation and the politics of 'trust'. In: M. Ekstrom, M. Patrona (Eds.). Talking Politics in Broadcast Media: Cross Cultural Perspectives on Political Interviewing, Journalism and Accountability. Amsterdam: Benjamins.

Tolson, A. (2012). "You'll need a miracle to win this election"'(J. Paxman 2005): Interviewer assertiveness in UK general elections 1983-2010, Discourse, Context \& Media, 1, 45-53.

Weizman, E. (2008). Positioning in Media Dialogue: Negotiating roles in the news interview. Amsterdam \& Philadelphia: John Benjamins Publishing Co. 